\title{
Development of 'Video Bank' Based on Prehistoric Community Life at the Sangiran Site as an Independent Learning Media
}

\author{
https://doi.org/10.3991/ijet.v15i07.13257 \\ Slamet Sujud Purnawan Jati, Arif Subekti, Wahyu Djoko Sulistyo ( $\bowtie$ ) \\ Jurusan Sejarah Universitas Negeri Malang, Malang, Indonesia \\ wahyu.djoko.fis@um.ac.id
}

\begin{abstract}
Accessibility toward archaeological remains is a vital component in the Indonesian prehistoric lesson among students. Unfortunately, those archaeological relics are scattered in various places throughout Indonesia. Resources for prehistoric period both for lecturer and researcher are abundant, with resources being collected both on several museum and preservation center. The purpose of this paper is to provide an innovation of learning media through R\&D methodological phase onto Bank of Video on social prehistoric life in Sangiran sites as independent learning media. First step is the exploration to gain primary data and the preparation of video's plot held in Sangiran, Sragen, Central Java. Second phase is development process to validate the draft and limited experiment, in order to deliver "normal" accomplishment. The last process, since several revisions of previous stages, is implementation of media, which average outcome is $>80$. It elucidates the effectiveness of Bank of Video as learning media.
\end{abstract}

Keywords_-Video Bank, prehistoric site, Sangiran.

\section{Introduction}

Indonesia was the country enrich with archaeological remains as an evidence of the past of thousands and even million years of prehistoric society [1], [2]. Mode of learning in the course about prehistoric life as taught in History Department of Faculty of Social Science, Universitas Negeri Malang, was dominated by face-to-face activities pointed on lecturer's knowledge. Nowadays, the effectiveness of this type of conventional learning pattern were widely studied [3]. Meanwhile, the lecture plan is arranged in a format of 16 meetings in one semester, with the same and repeated activities [4]. The theory systematically delivered by lecturers for one semester is not comparable to the description of the object of its historical study. This is one of the problems in learning history[5], [6]. Well-advance technology providing an overview of the object of study 
was felt. It is paradox to the various sites that must be described to students. Whereas for many other historical material studies, many have used technology in their learning packaging [7]. Those various sites studying in this subject were very complex, yet separated in each region around Indonesia. The activity chosen by the lecturer to support this lecture is:

1. Inviting students to visit the site

2. Conduct field lectures.

Additional explanations of the lecturer related to what is and can be taught to students is casts while providing direct experience to students [8]. But the number of prehistoric sites whose distribution is scattered in several regions in Indonesia, especially Java [9] [11]. So, it is unattainable both for students and lecturers to visit it, considering inefficient and expensive issues. Therefore, one achievement in one semester of this course is only able to visit at least one site object.

Life-based curriculum as a new product implemented by Universitas Negeri Malang focuses on the target of achieving student graduation standards that are ready to compete globally [12] [14]. Equip students with a variety of life skills or at least embedded in the spirit of independence. Therefore learning on the lectures has been encouraged to apply technology as a learning innovation [15] [17]. Lectures were no longer dominated by direct face-to-face activities between students and lecturers but could utilize technology to replace those activities. In addition to learn more effectively and efficiently forming a value of independence in students [18], [19].

Those considerations promote us, as historians, playing some roles in tackling these problems [20]. That is by developing a learning innovation for the human life course of prehistory in the form of "Prehistoric Human Life-based Video Bank" as a medium for self-learning. This innovation is a collection of videos that display the site in a comprehensive and complex manner in various aspects. The production of this video bank could provide a succinct illumination among students regarding prehistoric sites that cannot be visited in all field activities. Assumptions of research and development of historical video learning media based on human life during prehistory as follows: First, video includes audiovisual learning media that involves the sense of hearing and vision and can develop students' interest in learning, especially history lessons. The gap between learning material and teaching history is very clear, so that effective learning media is needed, one of which is using video [21] [23]. Second, video are efficient media in learning because they can be used for both personal and large classes [24].

\section{$2 \quad$ Method}

This research uses development methods. As a series of procedural activities to develop a product [25], this method includes various stages:

1. Analysis to find out the problem and the level of need,

2. The design to prepare a model that is ready to be validated 
3. The development where the model design is validated by experts and improved, the implementation where the model been tested and evaluated though the final product [26].

To be sum up, the method could be divided into three main activities, namely exploration for material collection, product drafting and product testing [27], [28]. Those development was carried out systematically with the following design:

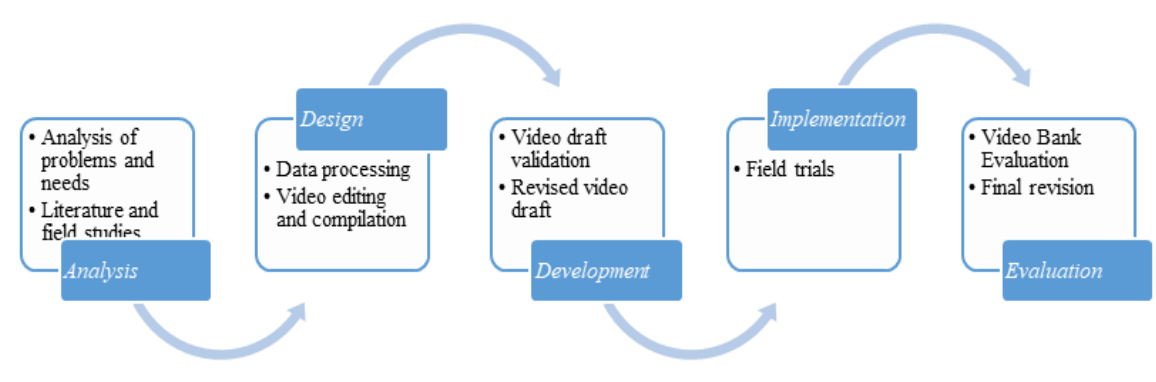

Fig. 1. Design of ADDIE Learning Innovation Development

\section{$3 \quad$ Result and Discussion}

\subsection{Product Specifications}

The development of learning innovation product depicted with the following product specifications:

a. A collection of videos from prehistoric sites in the Sangiran Museum, Sragen, Central Java. The museum being one of world heritages sites that holds many ancient collections [29] [31]. The selection of sites was adjusted to the competency standards that will be achieved through this course.

b. The amount and content of the video was adjusted by mapping the site distribution and scale of the lecture meeting in one semester, which is approximately 9 videos of learning that are aggressively called "Video Banks". Yet, this Video Bank has been divided into three broad groups of topics, namely: nature (stratigraphy), humans (the variety of skeletons and skulls of Meganthropus, Pithecanthropus, and Homo) [32] and cultural results in the form of tools [9]. The first topic was divided into 3 sub-sections:

1. Lower pleistocene

2. Middle Pleistocene

3. Upper Pleistocene. 
The second topic was divided as the various genera of early humans.

1. Meganthropus,

2. Pithecanthropus

3. Homo.

The third topic was also divided into three sub-sections.

1. Chopper-chopping tools complex

2. Flake-blade

3. Ngandong culture or Ngandong bone tools.

c. For the effectiveness and efficiency of the learning process, the duration of the video ranges from 15-20 minutes. The entire duration of the video includes prologue, core, and epilogue.

d. The Video Bank was planned, compiled and validated under the supervision and guidance of expert lecturers. Both audio and visual form of an in-depth lecturer explanation was showed artefactual evidence on the specified site.

\subsection{Product development}

In accordance with the stages of learning innovation development methodology, the main activity is the exploration of content material carrying data's mapping from literature review. The following stage is the compilation of videos. The research team conduct an exploration in Sangiran sites area. Video shooting was done directly in accordance with the requirements. The draft of narration would be made after the video capture was completed. Video editing activities were adjusted to the standards of learning media, both in appearance and content. After the drafting process complete, 'Video Bank' as an independent learning media would be submitted to the experts. The validator consists of historical learning media experts and material experts whose understand the substance of prehistoric human life.

For media experts who acted as validators were lecturers of learning media at the History Department, Universitas Negeri Malang, Ulfatun Nafi'ah and for material experts, one of the archaeologists from the same department, Deny Yudho. From the results of the validation by the two validators stated that video banks are feasible both material and methodological. The validator of media experts gave 82 score and material experts 86 . Both scores show the $\geq 80$ category. It means that the innovation classified on outstanding level. Even though it was declared feasible, the two validators gave general input and revised it as follows in table 1: 
Table 1. Results of Material and Media Validation

\begin{tabular}{|c|c|c|}
\hline Validator & Suggestion & Revision \\
\hline \multirow{2}{*}{$\begin{array}{l}\text { Material } \\
\text { Expert }\end{array}$} & $\begin{array}{l}\text { The material for each video should be clearly } \\
\text { demarcated, instead to be overlap }\end{array}$ & $\begin{array}{l}\text { Splitting video into mapped material } \\
\text { according to product specifications }\end{array}$ \\
\hline & $\begin{array}{l}\text { Each material described should be illustrated by } \\
\text { sample image }\end{array}$ & $\begin{array}{l}\text { Giving additional pictures as supporting } \\
\text { explanations }\end{array}$ \\
\hline \multirow{2}{*}{ Media Expert } & $\begin{array}{l}\text { The images of 1st video should display normally. } \\
\text { Do not zoom it. }\end{array}$ & Normalizing the quality of 1 st video \\
\hline & $\begin{array}{l}\text { It is good filtering the sound to make the sound } \\
\text { clearer }\end{array}$ & Re-filtering for performed audio \\
\hline
\end{tabular}

After the revision of the validator input was done and the product was ready to be tested, a small limited trial group was conducted with a sample of rundown from students majoring in History Department. This small trial group conducted on 10 students to watch the video bank and then conduct an evaluation. The results of this trial illustrated generally on the following data in table 2.

From the results of product trials in small groups, results were obtained stating that Video Bank development products fulfilled the eligibility criteria to be used as a medium. From an evaluation questionnaire consisting of 5 indicator items about the media as a whole, reaching a percentage of $78 \%$, which meant "outstanding". However, there is one item whose achievement value can be increased through the revised notes given by limited trial participants, which is item number 1 for aspects of video image quality. Meanwhile, number 2 are considered unclear and number 3 are considered to be too long. Therefore, some inputs from the subject of the trial will be revised at the stage of product improvement at the next stage.

Table 2. Limited Trial Results

\begin{tabular}{|c|l|c|c|c|c|c|c|c|c|c|c|c|}
\hline No. & Indicator & $\mathbf{1}$ & $\mathbf{2}$ & $\mathbf{3}$ & $\mathbf{4}$ & $\mathbf{5}$ & $\mathbf{6}$ & $\mathbf{7}$ & $\mathbf{8}$ & $\mathbf{9}$ & $\mathbf{1 0}$ & Tot \\
\hline 1 & Picture & 3 & 3 & 4 & 4 & 3 & 3 & 3 & 2 & 2 & 3 & $75 \%$ \\
\hline 2 & Sound & 3 & 3 & 2 & 2 & 4 & 3 & 2 & 2 & 4 & 4 & $72,5 \%$ \\
\hline 3 & Duration & 3 & 4 & 4 & 4 & 3 & 2 & 2 & 2 & 3 & 2 & $72,5 \%$ \\
\hline 4 & Information & 4 & 3 & 3 & 4 & 4 & 4 & 4 & 3 & 3 & 4 & $90 \%$ \\
\hline 5 & Completeness & 3 & 3 & 3 & 3 & 4 & 3 & 3 & 4 & 3 & 3 & $80 \%$ \\
\hline Total & 16 & 16 & 16 & 17 & 18 & 15 & 14 & 13 & 15 & 16 & $390 \%$ \\
\hline Average & 8 & 8 & 8 & 8,5 & 9 & 7,5 & 7 & 6,5 & 7,5 & 8 & $78 \%$ \\
\hline
\end{tabular}

\subsection{Product revision/ Product improvement}

At a glance, the results at the first trial stage already has shown good results with a percentage of $78 \%$. Therefore, this revision stage at the same time become the stage of refinement before the product would be implemented in the class. At this stage of product refinement, it is based on inputs written by students during the small trial. The following are some entries that have been reduced by the developer and product revision / improvement activities are carried out: 
Paper-Development of 'Video Bank' Based on Prehistoric Community Life at The Sangiran Site ..

Table 3. Limited Test Recommendations and Revised Tests

\begin{tabular}{|l|l|}
\hline \multicolumn{1}{|c|}{ Suggestion } & \multicolumn{1}{c|}{ Revision } \\
\hline $\begin{array}{l}\text { Add an introductory video from expert lecturers } \\
\text { and make running text for long duration videos }\end{array}$ & $\begin{array}{l}\text { Make an introductory video, and divide it into } \\
\text { several sub videos }\end{array}$ \\
\hline $\begin{array}{l}\text { Images of the video are too dark, and need to be } \\
\text { adjusted in contrast }\end{array}$ & $\begin{array}{l}\text { Adjust resetting and reprocessing the quality of } \\
\text { video image }\end{array}$ \\
\hline $\begin{array}{l}\text { Item } 4 \text { which contains audio clarity gets a low } \\
\text { point considering there are some videos, } \\
\text { especially outdoor video audio quality which is } \\
\text { low and unclear }\end{array}$ & Maximize sound especially on videos 6,7 and 8 \\
\hline $\begin{array}{l}\text { Clarify the image settings for indoor videos that } \\
\text { contain museum collections and play zoom out for } \\
\text { several segments in the explanation of the subject } \\
\text { matter }\end{array}$ & $\begin{array}{l}\text { Rearrange the image quality editing process, both } \\
\text { by adjusting the brightness and zooming out for } \\
\text { some video details. }\end{array}$ \\
\hline
\end{tabular}

Based on the input from limited trial participants, the next step is to improve the video that is developed both in appearance and content so that the results are obtained (fig 2).

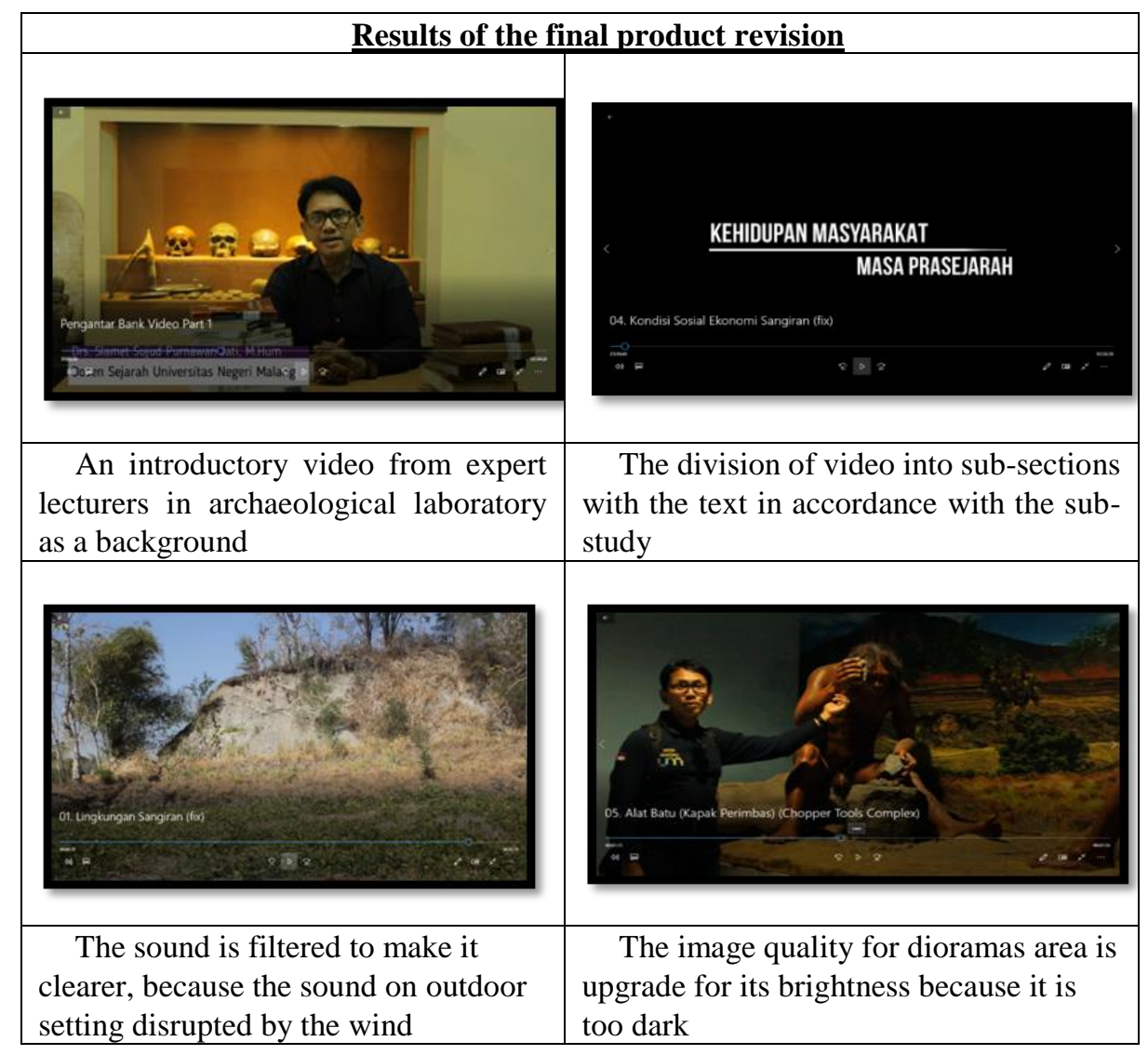




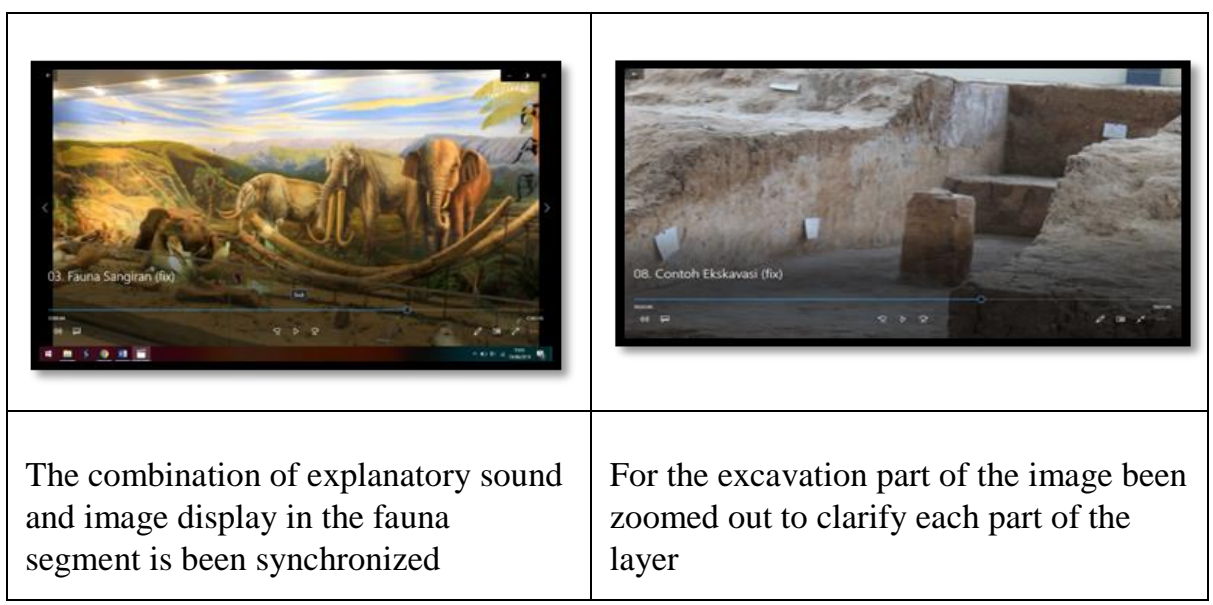

Fig. 2. Results of Limited Trial Revisions

\subsection{Product implementation}

The implementation of the "Video Bank " in the classroom was conducted at the course of Indonesia during the prehistoric period, particularly at the 9th meeting on October 16, 2018 at 7-10 hours in the room number 404. Accessibility and suitability of the course was the background for the chosen class. The number of participants in the implementation test consisted of 40 students with a balanced composition between the number of men and women. For the distribution of the initial abilities possessed by students is very diverse as a number of cognitive abilities, some are at moderate and high low levels. In short, there is no dominance. So that it can be ascertained if the class chosen in this trial is a class that is heterogeneous class and appropriate with the criteria of a trial class (fig. 3 ). 


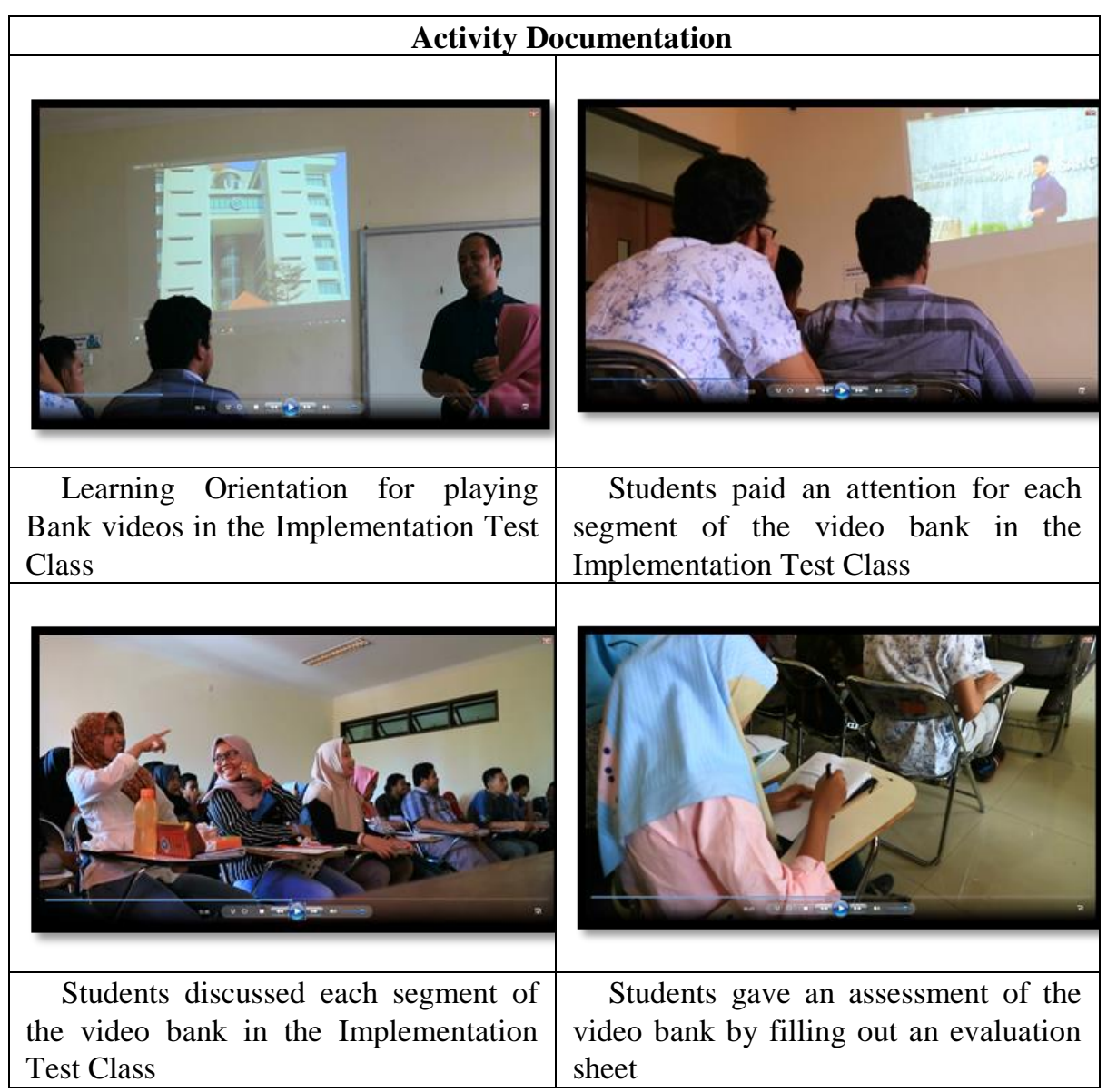

Fig. 3. Documentation of Implementation Test Activities

Based on the questionnaire that we gave to the user when the implementation test to provide an evaluation of the product that we were testing to 30 students, the following data were obtained (fig. 4). 

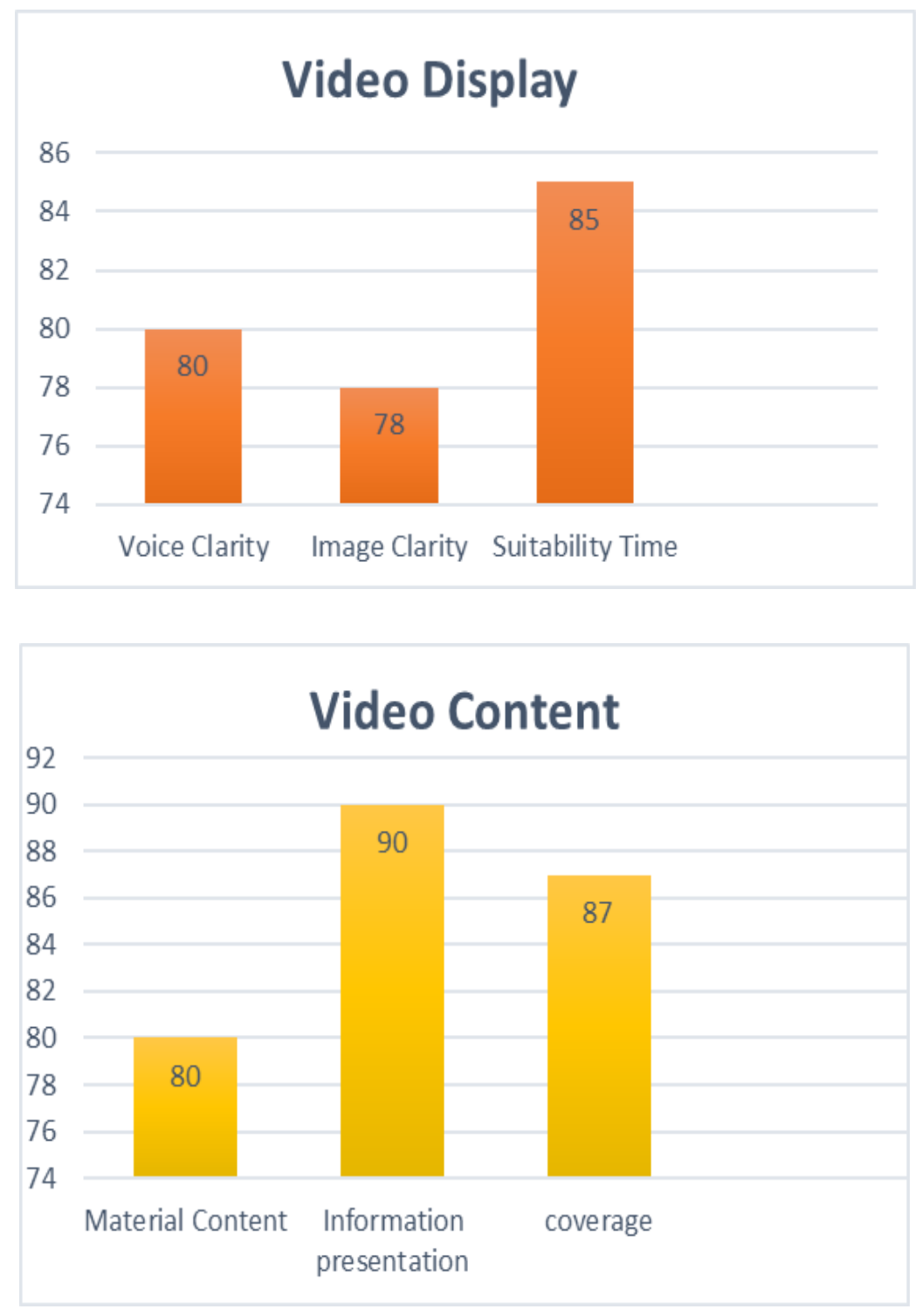

Fig. 4. Implementation Test Result Diagram

Based on the data from the analysis of the implementation test above shows the average achievement of 15 indicators to answer the feasibility of the 3 components of the video display which includes sound clarity reaching 80 accumulative values, 78 picture clarity and 85 timeliness. Means the average for video display reaches a number 81 , this shows that the display of "Video Bank " is declared feasible as an independent learning media. Furthermore, for the contents of the video, based on the questionnaire 
filled out by the extensive trial participants, it shows the achievements for the material content 80 , information presentation 90 and the suitability of the 87 . The average achievement of the content of the video is 86 , this shows that "Video Bank " or the content is very feasible as an independent learning media.

From the results of the above data, it can be concluded that the development of a Video Bank as a media for learning history independently can be one of the answers to the problems that faced. The general assumption that history learning is less interesting and undeniably monotonous learning with learning innovation 'this 'Video Bank'. The results of the implementation test show that the achievement of the average number for all assessments is above the number 80 , which means generally that the media are 'effective' video banks in their use. The packaging of the material in the form of interactive videos arranged with the appearance of the current audio-visual quality was able to get a positive response from the students. With this innovation, the hope that arose was a new mode of learning history, especially those that cover material about the prehistoric period in Indonesia, can utilize the results of this development to become an effective alternative learning media.

\section{Conclusion}

Innovation development in historical learning in the form of self-learning media packaged into a video collection or called 'Video Bank' is one of the answers to the challenges of historical learning conditions. Especially for historical material regarding the prehistoric period in Indonesia is a period that is too far in the span of time in the periodic study of history in Indonesia. Therefore, the researcher made a new breakthrough by compiling this 'learning media' 'Video Bank' by utilizing the Archaeological Site in Sangiran, which is rich in artifacts and fossils from the Prehistoric Period in Indonesia. Video Bank development process through scientific stages in the research and development methodology. The results of this study are the creation of video bank learning media that have gone through stages, material exploration and video material extraction on the Sangiran site, video preparation and editing, Validation process by material and media experts, limited product testing and the last is the implementation stage for test the effectiveness of the media. The results of the effectiveness test with evaluation from the implementation test participants for each content showed an average number above 80 . This shows that based on these achievements the Video Bank is very effective as an independent learning media that is in accordance with the needs of the times.

\section{$5 \quad$ References}

[1] T. Abdullah and B. L. Adrian, "Indonesia dalam Arus Sejarah Jilid I," Jkt. PT Ichtiar Baru Van Hoeve Bekerja Sama Dengan Kementeri. Pendidik. Dan Kebud. RI, 2012.

[2] R. P. Soejono, Sejarah Nasional Indonesia. Departemen Pendidikan dan Kebudayaan, Direktorat Sejarah dan Nilai, 1981. 
[3] D. Rohrer and H. Pashler, "Recent research on human learning challenges conventional instructional strategies," Educ. Res., vol. 39, no. 5, pp. 406-412, 2010. https://doi.org/10. $\underline{3102 / 0013189 X 10374770}$

[4] Universitas Negeri Malang, Pedoman Pendidikan Universitas Negeri Malang, Tahun Akademik 2017/2018. Malang: Biro Akademik, Kemahasiswaan, Perencanaan, Informasi, dan Kerjasama Universitas Negeri Malang, 2017.

[5] S. H. Hasan, "Problematika Pendidikan Sejarah," Bdg. FPIPS UPI, 2003.

[6] S. K. Kochar, Teaching of History. Jakarta: PT Grasindo, 2008.

[7] W. D. Sulistyo, U. Nafi'ah, and I. Idris, "The Development of E-PAS Based on Massive Open Online Courses (MOOC) on Local History Materials," Int. J. Emerg. Technol. Learn. IJET, vol. 14, no. 09, pp. 119-129, May 2019. https://doi.org/10.3991/ijet.v14i09.10143

[8] Jurusan Sejarah FIS UM, Katalog Jurusan Sejarah Edisi 2017. Malang: Jurusan Sejarah FIS UM, 2017.

[9] G.-J. Bartstra, "SOME REMARKS UPON: FOSSIL MAN FROM JAVA, HIS AGE, AND HIS TOOLS," Bijdr. Tot Taal- Land- En Volkenkd., vol. 139, no. 4, pp. 421-434, 1983. https://doi.org/10.1163/22134379-90003436

[10] R. Indraningsih, "Research on prehistoric beads in Indonesia," Bull. Indo-Pac. Prehistory Assoc., vol. 6, pp. 133-141, 1985. https://doi.org/10.7152/bippa.v6i0.11245

[11] P.-Y. Manguin and A. Indradjaja, "The Batujaya site: new evidence of early Indian influence in West Java," Early Interact. South Southeast Asia, pp. 113-36, 2011. https://doi.org/10. $\underline{1355 / 9789814311175-008}$

[12] S. Marginson, "Dynamics of national and global competition in higher education," High. Educ., vol. 52, no. 1, pp. 1-39, 2006. https://doi.org/10.1007/s10734-004-7649-x

[13] S. Marginson, "National and global competition in higher education," Aust. Educ. Res., vol. 31, no. 2, pp. 1-28, 2004. https://doi.org/10.1007/BF03249517

[14] V. Rust, L. Portnoi, and S. Bagley, Higher education, policy, and the global competition phenomenon. Springer, 2010. https://doi.org/10.1057/9780230106130

[15] C. B. Davison and E. J. Lazaros, "Adopting Mobile Technology in the Higher Education Classroom,” J. Technol. Stud., vol. 41, no. 1, Apr. 2015. https://doi.org/10.21061/jots. v41i1.a.4

[16] Y.-C. Hsu et al., "Research Trends in Technology-based Learning from 2000 to 2009: A content Analysis of Publications in Selected Journals," J. Educ. Technol. Soc., vol. 15, no. 2, pp. 354-370, 2012.

[17] D. Lin, "Application of a Big Data Platform in the Course of Java Language Programming," Int. J. Emerg. Technol. Learn. IJET, vol. 11, no. 10, pp. 16-21, Oct. 2016. https://doi.org/10. 3991/ijet.v11i10.6264

[18] C. Lury, Cultural rights: Technology, legality and personality. Routledge, 2002. https://doi.org/10.4324/9780203422892

[19] G. M. Thomas, "The cultural and religious character of world society," in Religion, Globalization, and Culture, Brill, 2007, pp. 35-56. https://doi.org/10.1163/ej.9789004 $\underline{154070 . i-608.15}$

[20] H. Saito, "The Role of Historians in the History Problem," in The History Problem, University of Hawai'i Press, 2017, pp. 155-177. https://doi.org/10.1515/9780824856779$\underline{008}$

[21] M. Giannakos, K. Chorianopoulos, M. Ronchetti, P. Szegedi, and S. Teasley, "Video-Based Learning and Open Online Courses," Int. J. Emerg. Technol. Learn. IJET, vol. 9, no. 1, pp. 4-7, Feb. 2014. https://doi.org/10.3991/ijet.v9i1.3354 
[22] A. M. Gabor and R. Vasiu, "Integration Solutions for Video Data in Educational Platforms," Int. J. Emerg. Technol. Learn. IJET, vol. 9, no. 8, pp. 11-15, May 2014. https://doi.org/10. 3991/ijet.v9i8.3482

[23] M. Girod, J. Bell, and P. Mishra, "Using Digital Video to Re-Think Teaching Practices,” p. 7, 2007.

[24] M. G. Sherin and E. B. Dyer, "Teacher self-captured video: Learning to see," Phi Delta Kappan, vol. 98, no. 7, pp. 49-54, Apr. 2017. https://doi.org/10.1177/0031721717702632

[25] M. D. Gall, W. R. Borg, and J. P. Gall, Educational research: An introduction. Longman Publishing, 1996.

[26] W. C. Dick, L. \& Carey, J. (2009). The systematic design of instruction. NJ: Upper Saddle River. Pearson, 81.

[27] J. W. Creswell and J. D. Creswell, Research design: Qualitative, quantitative, and mixed methods approaches. Sage publications, 2017.

[28] N. S. Sukmadinata, Metode Penelitian Pendidikan, 12th ed. Bandung: PT Remaja Rosdakarya, 2017.

[29] S. Dwiyantoro, "Museum Sangiran (Historisitas dan Relevansinya Sebagai Sumber Pembelajaran Sejarah)," 2012.

[30] M. Morwood, "Review of Sangiran: Man, Culture, and Environment in Pleistocene Times: Proceedings of the International Colloquium on Sangiran, Solo-Indonesia, 21-24 September 1998," Asian Perspect., vol. 43, no. 2, pp. 364-366, 2004. https://doi.org/10.1353/asi. $\underline{2004.0023}$

[31] M. C. Westaway, A. Durband, and D. Lambert, "Human evolution in Sunda and Sahul and the continuing contributions of Professor Colin Groves," in Taxonomic Tapestries, A. M. Behie and M. F. Oxenham, Eds. ANU Press, 2015, pp. 249-276. https://doi.org/10. 22459/TT.05.2015.12

[32] H. Baba, F. Aziz, Y. Kaifu, G. Suwa, R. T. Kono, and T. Jacob, "Homo erectus Calvarium from the Pleistocene of Java," Science, vol. 299, no. 5611, pp. 1384-1388, 2003. https://doi.org/10.1126/science.1081676

\section{Authors}

Slamet Sujud Purnawan Jati, is member of lecturer in History Department, Faculty of Social Sciences, Universitas Negeri Malang. His main research interest is archaeological studies and multidimensional approach on history.

Arif Subekti, lecturer in History Department, Faculty of Social Sciences, Universitas Negeri Malang. His main research interests are modern history of Indonesia, memory studies, and Islamic and political studies.

Wahyu Djoko Sulistyo is an Indonesian Historical Education, one of the lecturers in History Department, Faculty of Social Science, Universitas Negeri Malang. He is interested in educational history and learning innovation. Email: wahyu.djoko.fis @um.ac.id

Article submitted 2020-02-19. Resubmitted 2020-03-17. Final acceptance 2020-03-19. Final version published as submitted by the authors. 